\title{
ANALISIS ASUPAN MAKAN, KUALITAS TIDUR DAN TEKANAN DARAH PADA MAHASISWA OVERWEIGHT
}

\section{DIETARY INTAKE, SLEEP QUALITY AND BLOOD PRESSURE ANALYSIS AMONG OVERWEIGHT STUDENTS}

\author{
Zuhelviyani $^{1}$, Nurhaedar Jafar ${ }^{1}$, Healthy Hidayanti ${ }^{1}$ Djunaedi M Dachlan $^{1}$ \\ Abdul Salam ${ }^{1}$
}

(Email / Hp: zuhelviyani@gmail.com/ 081543116599)

${ }^{1}$ Program Studi Ilmu Gizi, Fakultas Kesehatan Masyarakat, Universitas Hasanuddin, Makassar

\begin{abstract}
ABSTRAK
Pendahuluan: Hipertensi sering juga disebut sebagai silent killer. Prevalensi hipertensi di Indonesia menurut data Riskesdas 2018 pada usia 18 - 24 tahun sebesar 13,2\%, usia 25 - 34 tahun sebesar 20,13\% dan usia 35 - 44 tahun sebesar 31,61\%. Tujuan : Penelitian ini bertujuan untuk mengetahui hubungan antara asupan makan dan kualitas tidur dengan tekanan darah pada mahasiswa overweight Fakultas Kesehatan Masyarakat Universitas Hasanuddin. Bahan dan Metode: Penelitian ini menggunakan jenis penelitian observasional analitik dengan desain cross sectional. Sampel penelitian ini adalah mahasiswa overweight usia $\geq 18$ tahun dengan sampel sebanyak 76 orang. Teknik pengambilan sampling ialah dengan menggunakan teknik total sampling, Hasil: Hasil penelitian ini didapatkan bahwa sebanyak 76 mahasiswa overweight Fakultas Kesehatan Masyarakat Universitas Hasanuddin memiliki asupan lemak kurang sebanyak 56,6\%, asupan serat kurang sebanyak 100\%, asupan natrium kurang sebanyak 85,5\%, asupan kalium kurang sebanyak 100\%, kemudian mayoritas memiliki kualitas tidur buruk sebanyak $80,3 \%$ serta memiliki tekanan darah sistolik normal sebanyak 65,8\% dan tekanan darah diastolik normal sebanyak 51,3\%. Hasil uji chi square yang dilakukan menunjukkan tidak terdapat hubungan signifikan antara asupan makan dengan tekanan darah $(\mathrm{p}>0,05)$ dan tidak terdapat hubungan signifikan antara kualitas tidur dengan tekanan darah ( $p>0,05)$. Kesimpulan: Tidak terdapat hubungan antara asupan makan (asupan lemak, serat, natrium dan kalium) dan kualitas tidur dengan tekanan darah pada mahasiswa overweight Fakultas Kesehatan Masyarakat Universitas Hasanuddin.
\end{abstract}

Kata Kunci : Asupan Makan, Kualitas Tidur, Tekanan Darah, Mahasiswa, Overweight

\section{ABSTRACT}

Introduction: Hypertension is often called "the silent killer". Hypertension prevalence in Indonesia based on Riskesdas in 2018 was 13,2\% among adults aged 18 - 24 years, 20,13\% among those aged 25 - 34 years, 31,61\% among those aged 35 - 44 years. Aims: The purpose of this study is to determine the relationships between dietary intake, sleep quality index and blood pressure in overweight students of Public Health Faculty Hasanuddin University. Materials and Methods: This study is used observational analytic with cross sectional design. The sample of this study is overweight students aged $\geq 18$ years. 76 samples 
were obtained. The sampling technique in this study is using total sampling. Results: The results of this study found that 76 overweight students of Public Health Hasanuddin University has low fat intake were 56,6\%, low dietary fiber intake were 100\%, low sodium intake were $85,5 \%$, low potassium intake were $100 \%$, and majority has bad sleep quality were $80,3 \%$ and has normal systolic blood pressure were 65,8\% and has normal diastolic blood pressure were 51,3\%. In this study, the results obtained based on Chi-Square statistical tests that there is no significant relationship between dietary intake and blood pressure $(p>0,05)$ and there is no significant relationship between sleep quality and blood pressure ( $p>0,05)$. Conclusions: There is no relationship between dietary intake (fat intake, dietary fiber intake, sodium intake and potassium intake), sleep quality amd blood pressure among overweight students in Public Health Faculty Hasanuddin University.

\section{Keywords: Dietary Intake, Sleep Quality, Blood Pressure, University Students, Overweight}

\section{PENDAHULUAN}

Hipertensi sering juga disebut sebagai silent killer. ${ }^{l}$ Hal ini dikarenakan hipertensi tidak memiliki tanda ataupun gejala sampai secara signifikan terjadi kerusakan pada jantung dan arteri. ${ }^{1}$ Oleh karena itu sangat perlu untuk melakukan pengukuran tekanan darah secara rutin. ${ }^{1}$ Prevalensi hipertensi secara global menurut WHO terbagi atas kelompok pendapatan yang rendah yaitu wilayah Afrika yang mana memiliki prevalensi hipertensi tertinggi sebesar $27 \%$ sedangkan pada wilayah pendapatan tinggi yaitu Amerika memiliki prevalensi hipertensi yang rendah sebesar $18 \%$. $^{2}$ Angka kejadian hipertensi pada usia 18 tahun - 23 tahun mengalami peningkatan dari 594 juta pada tahun 1975 menjadi 1,13 milyar pada tahun 2015 di dunia $^{2}$

Berdasarkan data riskesdas tahun 2007 - 2018, prevalensi hipertensi pada usia 18 tahun - 24 tahun di Indonesia berdasarkan pengukuran tekanan darah menurut riskesdas (2007) terdapat sebesar $12,2 \%$ penduduk Indonesia yang diukur memiliki hipertensi sedangkan pada tahun 2013 menurut riskesdas 2013 terdapat penurunan dari 12,2\% menjadi 8,7\% pada tahun 2013. ${ }^{3,4}$ Namun, terdapat peningkatan prevalensi hipertensi berdasarkan wawancara dimana $1,8 \%$ pada tahun 2007 menjadi $2,4 \%$ di tahun $2013 .{ }^{3,4}$ Hal ini terjadi bisa dikarenakan penggunaan alat tensi yang berbeda maupun masyarakat yang telah mulai datang berobat ke fasilitas kesehatan. ${ }^{4}$ Adapun berdasarkan data riskesdas 2018 didapatkan sebesar $13,2 \%$ yang menderita hipertensi. ${ }^{5}$ Hal ini menunjukkan terjadinya peningkatan dari $8,7 \%$ pada tahun 2013 menjadi 13,2\% pada tahun 2018. ${ }^{4,5}$ Adapun prevalensi hipertensi pada umur 25 - 34 tahun menurut data riskesdas tahun 2007 - 2018 didapatkan sebanyak 19\% orang indonesia yang diukur memiliki hipertensi pada tahun 2007 dan pada tahun 2013 menurun menjadi $14,7 \%$ dan meningkat menjadi $20,13 \%$ pada tahun $2018 .^{3,4,5}$ Kemudian prevalensi hipertensi pada umur 35 - 44 tahun menurut data riskesdas 2007 - 2018 didapatkan sebanyak $29,9 \%$ orang Indonesia yang diukur memiliki hipertensi pada tahun $2007 .{ }^{3}$ Kemudian pada tahun 2013 mengalami penurunan menjadi 24,8\% pada tahun 2013. ${ }^{4}$ Dan mengalami peningkatan pada tahun 2018 menjadi $31,61 \% .^{5}$

Prevalensi hipertensi di Sulawesi Selatan pada kelompok umur $\geq 18$ tahun menurut data riskesdas 2007 dimana berdasarkan wawancara sebesar 11,6\% serta menurut data pengukuran sebesar 29\%. ${ }^{6}$ Adapun menurut riskesdas 2013 dimana berdasarkan data 
wawancara sebesar 20,8\% dan berdasarkan pengukuran sebesar $28,1 \%{ }^{7}$ Hal ini menunjukkan terdapat penurunan prevalensi hipertensi di Sulawesi Selatan menurut pengukuran dari $29 \%$ di tahun 2007 menjadi 28,1\% di tahun 2013. ${ }^{6,7}$ Namun, berdasarkan data wawancara terjadi peningkatan dari $11,6 \%$ pada tahun 2007 menjadi 20,8\% pada tahun $2013 .{ }^{6,7} \mathrm{Hal}$ ini terjadi bisa dikarenakan penggunaan alat tensi yang berbeda maupun masyarakat yang telah mulai datang berobat ke fasilitas kesehatan. ${ }^{7}$ Sedangkan menurut data riskesdas tahun 2018 sebanyak $31,68 \%$ berdasarkan data pengukuran dan menurut data wawancara sebesar $14,99 \% .^{5}$ Hal ini menunjukkan terdapat peningkatan dari $28,1 \%$ pada tahun 2013 menjadi $31,68 \%$ pada tahun 2018 dan mengalami penurunan berdasarkan data wawancara $20,8 \%$ di tahun 2013 menjadi 14,99\% pada tahun 2018. ,7 $^{5,7}$

Ada beberapa penelitian yang terkait hubungan asupan makan dengan tekanan darah seperti halnya dengan penelitian yang dilakukan oleh Miftah Nur Andamsari (2015) menunjukkan bahwa terdapat hubungan antara konsumsi lemak dengan tekanan darah sistolik tetapi tidak terdapat hubungan konsumsi lemak dengan tekanan darah diastolik. ${ }^{8}$ Penelitian yang dilakukan oleh Saharuddin (2018) menunjukkan konsumsi natrium memiliki hubungan dengan kejadian hipertensi. ${ }^{9}$ Kemudian penelitian yang dilakukan oleh Arlita Tri Widyaningrum (2014) dimana hasil penelitian yang dilakukannya terdapat hubungan antara asupan natrium, kalium, magnesium dan status gizi dengan tekanan darah pada lansia di Kelurahan Makamhaji Kecamatan Kartasura. ${ }^{10}$ Penelitian lainnya yang dilakukan oleh Mery Andika Putri (2016) menunjukkan bahwa terdapat hubungan asupan serat, natrium dan aktivitas fisik dengan tekanan darah sistolik dan diastolik di Unit Rawat Jalan UPTD Puskesmas Pajang Surakarta. ${ }^{11}$

Adapun penelitian yang berkaitan dengan hubungan kualitas tidur dengan tekanan darah. Seperti penelitian yang dilakukan Annisa Aulia Fitri (2013) menunjukkan terdapat hubungan antara kualitas tidur dan hipertensi pada pasien Unit Pelayanan Jantung Terpadu RSPUN Dr. Cipto Mangunkusumo Jakarta. ${ }^{12}$

Seperti yang dijelaskan sebelumnya bahwa beberapa faktor risiko dari penyakit hipertensi ialah asupan lemak, serat, natrium dan kalium serta kualitas tidur. Oleh karena itu, dari faktor risiko tersebut peneliti tertarik untuk meneliti kedua faktor risiko ini terhadap tekanan darah pada mahasiswa overweight Fakultas Kesehatan Masyarakat Universitas Hasanuddin.

\section{BAHAN DAN METODE}

Tujuan dari penelitian ini adalah untuk mengetahui hubungan asupan makan dan kualitas tidur dengan tekanan darah pada mahasiswa overweight Fakultas Kesehatan Masyarakat Universitas Hasanuddin. Sampel pada penelitian ini ialah mahasiswa overweight yang memenuhi syarat inklusi dan eksklusi. Adapun syarat inklusi dari penelitian ini adalah berusia $\geq 18$ tahun, bersedia menjadi responden dalam penelitian ini, terdaftar menjadi mahasiswa Fakultas Kesehatan Masyarakat Universitas Hasanuddin, aktif dalam aktivitas perkuliahan Fakultas Kesehatan Masyarakat Universitas Hasanuddin dan memiliki status gizi overweight dengan Indeks Massa Tubuh $\geq 25,00$ atau lingkar perut $>80 \mathrm{~cm}$ untuk perempuan dan $>90 \mathrm{~cm}$ untuk laki-laki. Sedangkan syarat eksklusi dari penelitian ini adalah usia $<18$ tahun dan memiliki status gizi normal atau kurang gizi dengan Indeks Massa Tubuh $\leq 24,99$. 
Jenis penelitian yang digunakan adalah observasional analitik dengan rancangan cross sectional. Sampel penelitian ini adalah mahasiswa overweight. Didapatkan sebanyak 76 sampel. Adapun teknik pengambilan sampel dilakukan menggunakan total sampling. Dimana sampel penelitian di ukur tinggi badan (menggunakan microtoice) dan di timbang berat badannya (menggunakan timbangan) kemudian dihitung Indeks Massa Tubuhnya menggunakan rumus Indeks Massa Tubuh untuk mengetahui apakah memenuhi kriteria inklusi dan eksklusi. Asupan makan (asupan lemak, serat, natrium dan kalium) di ukur dengan cara wawancara menggunakan recall 24 jam selama dua hari yang dilakukan pada hari kerja dan hari libur. Setelah itu, data dianalisis menggunakan aplikasi nutrisurvey dan juga dibantu dengan Daftar Komposisi Bahan Makanan (DKBM) untuk mengetahui jumlah asupan makan responden dan dihitung serta dibandingkan dengan kebutuhan dan Angka Kecukupan Gizi (AKG). Kemudian kualitas tidur responden di ukur menggunakan kuesioner Pittsburgh Sleep Quality Index (PSQI) yang diisi sendiri oleh responden dan tekanan darah responden di ukur menggunakan alat tensi digital yang di ukur oleh peneliti. setelah itu semua data dianalisis menggunakan aplikasi SPSS dan Microsoft Excel dengan menggunakan Uji Chi-Square.

\section{HASIL}

Hasil penelitian untuk screening status gizi responden menunjukkan sebanyak 92 orang dari jumlah populasi mahasiswa 1065 orang. Hal ini dikarenakan 92 orang mahasiswa tersebut diyakini memiliki Indeks Massa Tubuh Overweight dan obesitas (Indeks Massa Tubuh $\geq 25,00$ ) atau lingkar perut $>90 \mathrm{~cm}$ untuk laki-laki dan $>80 \mathrm{~cm}$ untuk perempuan berdasarkan bentuk tubuh. Dari 92 orang yang diukur berat badan dan tinggi badannya didapatkan 16 orang $(17,4 \%)$ yang memiliki Indeks Massa Tubuh normal, 66 orang $(71,7 \%)$ yang memiliki Indeks Massa Tubuh Overweight, 7 orang (7,6\%) yang memiliki Indeks Massa Tubuh Obesitas Kelas 1 dan 3 orang $(3,3 \%)$ yang memiliki Indeks Massa Tubuh Obesitas Kelas 2. Kemudian hasil screening berdasarkan lingkar perut didapatkan hasil dimana sebanyak 20 orang $(21,7 \%)$ yang memiliki lingkar perut normal dan 72 orang $(78,3 \%)$ yang memiliki lingkar perut kategori obesitas sentral. Dari 92 orang mahasiswa yang diukur status gizinya hanya 76 orang yang memenuhi kriteria inklusi penelitian dan menjadi subjek penelitian.

Tabel 1. Distribusi Hasil Screening Status Gizi Berdasarkan Indeks Massa Tubuh dan Lingkar Perut Responden

\begin{tabular}{ccc}
\hline Status Gizi & n & \% \\
\hline Indeks Massa Tubuh & 16 & 17.4 \\
Normal & 66 & 71.7 \\
Overweight & 7 & 7.6 \\
Obesitas Kelas 1 & 3 & 3.3 \\
Obesitas Kelas 2 & & \\
Lingkar Perut & 20 & 21.7 \\
Normal & 72 & 78.3 \\
Obesitas Sentral & 92 & 100.0
\end{tabular}

Sumber: Data Primer, 2019 
Hasil penelitian berdasarkan distribusi karakteristik responden menurut umur, jenis kelamin, program studi, angkatan dan riwayat penyakit. Karakteristik responden menurut umur didapatkan dari 76 responden yang diukur didominasi oleh responden yang memiliki memiliki umur 20 - 21 tahun sebanyak 38 orang (50\%). Kemudian berdasarkan jenis kelamin diperoleh hasil dimana mayoritas responden berjenis kelamin perempuan sebanyak 73 orang $(96,1 \%)$. Kemudian karakteristik responden menurut program studi didapatkan hasil dimana mayoritas responden berasal dari program studi Kesmas sebanyak 51 orang $(67,1 \%)$. Kemudian berdasarkan angkatan, mayoritas responden berasal dari angkatan 2017 yaitu sebanyak 26 orang $(34,2 \%)$. Adapun karakteristik responden berdasarkan riwayat penyakit responden dari 76 responden didapatkan mayoritas responden tidak memiliki riwayat penyakit sebanyak 52 orang $(68,4 \%)$.

Tabel 2. Distribusi Karakteristik Responden

\begin{tabular}{ccc}
\hline Karakteristik & $\mathbf{n}$ & $\%$ \\
\hline Umur & 35 & \\
$18-19$ & 38 & 46.1 \\
$20-21$ & 3 & 50.0 \\
$>21$ & & 3.9 \\
\hline Jenis Kelamin & 3 & 3.9 \\
Laki-Laki & 73 & 96.1 \\
Perempuan & & \\
Program Studi & 51 & 67.1 \\
Kesmas & 25 & 32.9 \\
Ilmu Gizi & 1 & \\
Angkatan & 15 & 1.3 \\
2015 & 26 & 19.7 \\
2016 & 20 & 34.2 \\
2017 & 12 & 26.3 \\
2018 & 2 & 15.8 \\
2019 & & 2.6 \\
Tubel & 1 & 1.3 \\
\hline Riwayat Penyakit & 3 & 3.9 \\
Gastritis & 2 & 2.6 \\
Asma & 2 & 2.6 \\
Asma, Maag & 1 & 1.3 \\
DBD & 8 & 10.5 \\
Infeksi Ginjal & 1 & 1.3 \\
Maag & 4 & 5.3 \\
Maag, Sinusitis & 2 & 2.6 \\
Maag, Tifus & 52 & 100.0 \\
Tifus & &
\end{tabular}

Sumber: Data Primer, 2019

Adapun asupan zat gizi responden berdasarkan asupan lemak, serat, natrium dan kalium didapatkan hasil dimana mayoritas responden memiliki asupan lemak dengan kategori kurang sebanyak 43 orang $(56,6 \%)$. Adapun karakteristik responden berdasarkan asupan serat 
didapatkan hasil dimana sebanyak 76 orang (100\%) memiliki asupan serat dengan kategori kurang. Kemudian karakteristik responden berdasarkan asupan natrium didapatkan hasil dimana mayoritas responden memiliki asupan natrium dengan kategori kurang sebanyak 65 orang $(85,5 \%)$. Kemudian karakteristik responden berdasarkan asupan kalium didapatkan hasil dimana sebanyak 76 orang (100\%) memiliki asupan kalium dengan kategori kurang.

Tabel 3. Distribusi Asupan Zat Gizi Responden Berdasarkan Asupan Lemak, Serat, Natrium dan Kalium

\begin{tabular}{ccc}
\hline Asupan Zat Gizi & n & \% \\
\hline Asupan Lemak & & 56.6 \\
Kurang & 43 & 26.3 \\
Cukup & 20 & 17.1 \\
Lebih & 13 & 100.0 \\
\hline Asupan Serat & & \\
Kurang & 76 & 85.5 \\
Asupan Natrium & & 14.5 \\
Kurang & 65 & 100.0 \\
Cukup & 11 & 100.0 \\
\hline Asupan Kalium & &
\end{tabular}

Sumber: Data Primer, 2019

Adapun distribusi kualitas tidur responden didapatkan hasil dimana dari 76 responden, mayoritas responden yaitu sebanyak 61 orang $(80,3 \%)$ memiliki kualitas tidur buruk.

Tabel 4. Distribusi Kualitas Tidur Responden

\begin{tabular}{cll}
\hline Kualitas Tidur & n & \% \\
\hline Baik & 15 & 19.7 \\
Buruk & 61 & 80.3 \\
\hline Total & 76 & 100.0
\end{tabular}

Sumber: Data Primer, 2019

Tabel 5. Distribusi Tekanan Darah Responden Berdasarkan Tekanan Darah Sistolik dan Tekanan Darah Diastolik

\begin{tabular}{ccc}
\hline Tekanan Darah & $\mathbf{n}$ & $\mathbf{\%}$ \\
\hline Tekanan Darah Sistolik & & \\
Normal & 48 & 63.2 \\
Hipertensi & 28 & 36.8 \\
\hline Tekanan Darah Diastolik & & \\
Normal & 37 & 48.7 \\
Hipertensi & 39 & 51.3 \\
\hline Total & 76 & 100.0
\end{tabular}

Sumber: Data primer, 2019

Distribusi tekanan darah responden berdasarkan tekanan darah sistolik dan tekanan darah diastolik didapatkan hasil dimana mayoritas responden memiliki tekanan darah sistolik dengan kategori normal sebanyak 50 orang $(65,8 \%)$. Sedangkan karakteristik responden 
berdasarkan tekanan darah diastolik didapatkan hasil dimana mayoritas responden memiliki tekanan darah diastolik dengan kategori normal sebanyak 39 orang $(51,3 \%)$.

Hasil analisis hubungan asupan lemak dengan tekanan darah sistolik menunjukkan bahwa responden yang memiliki asupan lemak kurang cenderung memiliki tekanan darah sistolik kategori normal dibandingkan tekanan darah sistolik kategori hipertensi yaitu sebanyak 29 orang $(67,4 \%)$. Kemudian responden dengan asupan lemak cukup cenderung memiliki tekanan darah sistolik kategori normal sebanyak 11 orang (55\%). Sedangkan responden dengan asupan lemak lebih cenderung memiliki tekanan darah sistolik kategori normal dibandingkan tekanan darah sistolik kategori hipertensi sebanyak 8 orang $(61,5 \%)$. Kemudian untuk menganalisis hubungan asupan lemak dengan tekanan darah sistolik dilakukan menggunakan analisis uji chi square. Hasil uji analisis chi square asupan lemak dengan tekanan darah sistolik didapatkan hasil tidak terdapat hubungan antara asupan lemak dengan tekanan darah sistolik atau $\mathrm{h}_{0}$ diterima $(\mathrm{p}=0,629)(\mathrm{p}>0,05)$.

Hasil analisis hubungan asupan lemak dengan tekanan darah diastolik menunjukkan bahwa responden yang memiliki asupan lemak kurang cenderung memiliki tekanan darah diastolik kategori normal dibandingkan tekanan darah diastolik kategori hipertensi yaitu sebanyak 25 orang $(58,1 \%)$. Kemudian responden dengan asupan lemak cukup cenderung memiliki tekanan darah diastolik kategori hipertensi sebanyak 13 orang (65\%). Sedangkan responden dengan asupan lemak lebih cenderung memiliki tekanan darah diastolik kategori hipertensi dibandingkan tekanan darah diastolik kategori normal sebanyak 8 orang $(61,5 \%)$. Kemudian untuk menganalisis hubungan asupan lemak dengan tekanan darah diastolik dilakukan menggunakan analisis uji chi square. Hasil uji analisis chi square asupan lemak dengan tekanan darah diastolik didapatkan hasil tidak terdapat hubungan antara asupan lemak dengan tekanan darah diastolik atau $\mathrm{h}_{0}$ diterima $(\mathrm{p}=0,167)(\mathrm{p}>0,05)$.

Hasil analisis hubungan asupan serat dengan tekanan darah sistolik menunjukkan bahwa semua responden memiliki asupan serat yang kurang (100\%) dimana mayoritas responden memiliki asupan serat kurang dengan tekanan darah sistolik kategori normal sebanyak 48 orang $(63,2 \%)$. Kemudian untuk menguji hubungan asupan serat dengan tekanan darah sistolik tidak dilakukan karena variabel uji tidak memenuhi syarat uji yaitu tabel berbentuk 1 x 3 .

Hasil analisis hubungan asupan serat dengan tekanan darah diastolik menunjukkan bahwa semua responden memiliki asupan serat yang kurang (100\%) dimana mayoritas responden memiliki asupan serat kurang dengan tekanan darah diastolik kategori hipertensi sebanyak 39 orang $(51,3 \%)$. Kemudian untuk menguji hubungan asupan serat dengan tekanan darah diastolik tidak dilakukan karena variabel uji tidak memenuhi syarat uji yaitu tabel berbentuk 1 x 3 . Hasil analisis hubungan asupan natrium dengan tekanan darah sistolik menunjukkan bahwa responden mayoritas memiliki asupan natrium kurang sebanyak 43 orang $(66,2 \%)$ dengan tekanan darah sistolik kategori normal. Kemudian responden dengan asupan natrium cukup mayoritas memiliki tekanan darah sistolik kategori hipertensi sebanyak 6 orang $(54,5 \%)$. Kemudian untuk menganalisis hubungan asupan natrium dengan tekanan darah sistolik dilakukan menggunakan analisis uji fisher. Hal ini dikarenakan terdapat 2 sel yang memiliki nilai expected kurang dari 5 sehingga tidak memenuhi syarat uji chi square. Hasil uji analisis fisher asupan natrium dengan tekanan darah sistolik didapatkan hasil tidak terdapat hubungan antara asupan natrium dengan tekanan darah sistolik atau $\mathrm{h}_{0}$ diterima $(\mathrm{p}=0,310)(\mathrm{p}>0,05)$. 
Hasil analisis hubungan asupan natrium dengan tekanan darah diastolik menunjukkan bahwa responden mayoritas memiliki asupan natrium kurang sebanyak 33 orang $(50,8 \%)$ dengan tekanan darah diastolik kategori hipertensi. Kemudian responden dengan asupan natrium cukup mayoritas memiliki tekanan darah diastolik kategori hipertensi sebanyak 6 orang (54,5\%). Kemudian untuk menganalisis hubungan asupan natrium dengan tekanan darah diastolik dilakukan menggunakan analisis uji chi square. Hasil uji analisis chi square asupan natrium dengan tekanan darah diastolik didapatkan hasil tidak terdapat hubungan antara asupan natrium dengan tekanan darah diastolik atau $\mathrm{h}_{0}$ diterima $(\mathrm{p}=0,817)(\mathrm{p}>0,05)$. Hasil analisis hubungan asupan kalium dengan tekanan darah sistolik menunjukkan bahwa semua responden memiliki asupan kalium yang kurang (100\%) dimana mayoritas responden memiliki asupan kalium kurang dengan tekanan darah sistolik kategori normal sebanyak 48 orang $(63,2 \%)$. Kemudian untuk menguji hubungan asupan kalium dengan tekanan darah sistolik tidak dilakukan karena variabel uji tidak memenuhi syarat uji yaitu tabel berbentuk 1 x 3 .

Hasil analisis hubungan asupan kalium dengan tekanan darah diastolik menunjukkan bahwa semua responden memiliki asupan kalium yang kurang (100\%) dimana mayoritas responden memiliki asupan kalium kurang dengan tekanan darah diastolik kategori hipertensi sebanyak 39 orang (51,3\%). Kemudian untuk menguji hubungan asupan kalium dengan tekanan darah diastolik tidak dilakukan karena variabel uji tidak memenuhi syarat uji yaitu tabel berbentuk 1 x 3 . Hasil analisis hubungan kualitas tidur dengan tekanan darah sistolik menunjukkan bahwa mayoritas responden yaitu sebanyak 10 orang $(66,7 \%)$ memiliki kualitas tidur baik dengan tekanan darah sistolik kategori normal. Kemudian sebanyak 38 orang $(62,3 \%)$ memiliki kualitas tidur buruk dengan tekanan darah sistolik kategori normal. Kemudian untuk menganalisis hubungan kualitas tidur dengan tekanan darah sistolik dilakukan menggunakan analisis uji chi square. Hasil uji analisis uji chi square kualitas tidur dengan tekanan darah sistolik didapatkan hasil tidak terdapat hubungan antara kualitas tidur dengan tekanan darah sistolik atau $\mathrm{h}_{0}$ diterima $(\mathrm{p}=0,753)(\mathrm{p}>0,05)$.

Tabel 6. Hubungan Kualitas Tidur dengan Tekanan Darah Sistolik

\begin{tabular}{crrrrrrr}
\hline KT & \multicolumn{6}{c}{ Tekanan Darah Sistolik } & \multirow{2}{*}{$* \boldsymbol{p}$} \\
& \multicolumn{2}{c}{ Normal } & \multicolumn{2}{c}{ HT } & \multicolumn{2}{c}{ Total } & \\
& $\mathrm{n}$ & $\%$ & $\mathrm{n}$ & $\%$ & $\mathrm{n}$ & $\%$ & \\
\hline Baik & 10 & 66.7 & 5 & 33.3 & 15 & 100.0 & 0,753 \\
Buruk & 38 & 62.3 & 23 & 37.7 & 61 & 100.0 & \\
\hline Total & $\mathbf{4 8}$ & $\mathbf{6 3 . 2}$ & $\mathbf{2 8}$ & $\mathbf{3 6 . 8}$ & $\mathbf{7 6}$ & $\mathbf{1 0 0 . 0}$ & \\
\hline
\end{tabular}

Sumber: Data primer, 2019

Hasil analisis hubungan kualitas tidur dengan tekanan darah diastolik menunjukkan bahwa mayoritas responden yaitu sebanyak 8 orang $(53,3 \%)$ memiliki kualitas tidur baik dengan tekanan darah diastolik kategori hipertensi. Kemudian sebanyak 31 orang $(50,8 \%)$ memiliki kualitas tidur buruk dengan tekanan darah diastolik kategori hipertensi. Kemudian untuk menganalisis hubungan kualitas tidur dengan tekanan darah diastolik dilakukan menggunakan analisis uji chi square. Hasil uji analisis uji chi square kualitas tidur dengan tekanan darah diastolik didapatkan hasil tidak terdapat hubungan antara kualitas tidur dengan tekanan darah diastolik atau $\mathrm{h}_{0}$ diterima $(\mathrm{p}=0,861)(\mathrm{p}>0,05)$. 
Tabel 7. Hubungan Kualitas Tidur dengan Tekanan Darah Diastolik

\begin{tabular}{cccccccc}
\hline KT & \multicolumn{6}{c}{ Tekanan Darah Diastolik } & $*$ \\
& Normal & \multicolumn{2}{c}{ HT } & \multicolumn{2}{c}{ Total } & \\
& $\mathrm{n}$ & $\%$ & $\mathrm{n}$ & $\%$ & $\mathrm{n}$ & $\%$ & \\
\hline Baik & 7 & 46.7 & 8 & 53.3 & 15 & 100.0 & 0,861 \\
Buruk & 30 & 49.2 & 31 & 50.8 & 61 & 100.0 & \\
Total & $\mathbf{3 7}$ & $\mathbf{4 8 . 7}$ & $\mathbf{3 9}$ & $\mathbf{5 1 . 3}$ & $\mathbf{7 6}$ & $\mathbf{1 0 0 . 0}$ & \\
\hline
\end{tabular}

Sumber: Data primer, 2019

\section{PEMBAHASAN}

Berdasarkan hasil analisis hubungan asupan lemak dengan tekanan darah sistolik dimana didapatkan sebagian besar responden memiliki asupan lemak kurang dengan tekanan darah sistolik normal sebanyak 29 orang $(67,4 \%)$ dan asupan lemak terbanyak kedua dari hasil analisis terdapat pada asupan lemak kurang dengan tekanan darah sistolik hipertensi sebanyak 12 orang $(32,6 \%)$. Sedangkan dengan asupan lemak lebih didominasi oleh mahasiswa yang memiliki tekanan darah sistolik normal sebanyak 8 orang $(61,5 \%)$. Dan hasil analisis menunjukkan tidak adanya hubungan $(\mathrm{p}=0,629)(\mathrm{p}>0,05)$ antara asupan lemak dengan tekanan darah sistolik pada mahasiswa Fakultas Kesehatan Masyarakat Universitas Hasanuddin. Dan begitupula dengan hasil analisis hubungan asupan lemak dengan tekanan darah diastolik dimana tidak terdapat hubungan antara keduanya $(\mathrm{p}=0,167)(\mathrm{p}>0,05)$. Dimana responden didominasi oleh mahasiswa dengan asupan lemak kurang dengan tekanan darah diastolik normal sebanyak 25 orang $(58,1 \%)$ dan disusul dengan asupan lemak kurang dengan tekanan darah diastolik hipertensi sebanyak 18 orang $(41,9 \%)$. Hal ini sejalan dengan penelitian yang dilakukan oleh Aria Menad (2016) dimana tidak terdapat hubungan asupan lemak dengan tekanan darah sistolik $(\mathrm{p}=-0,121)$ dan diastolik $(\mathrm{p}=0,473)$ dikarenakan sebagian besar responden memiliki asupan lemak kurang dari kebutuhan. ${ }^{13}$ Kemudian sejalan dengan penelitian yang dilakukan oleh Amalia Rahma (2019) dimana tidak terdapat hubungan asupan lemak dengan kejadian hipertensi $(\mathrm{p}=0,438){ }^{14}$

Adapun hubungan asupan serat dengan tekanan darah sistolik dan diastolik tidak dianalisis karena tidak memenuhi syarat uji yaitu tabel berbentuk 1 x 3 . Dimana konsumsi serat responden sebanyak 76 reponden dari 76 responden (100\%) memiliki asupan serat kurang. Asupan serat sebagian besar responden berasal dari protein nabati dan hanya sedikit yang mengkonsumsi sayuran dan buah dan sebagian responden hanya mengkonsumsi sayuran dalam jumlah yang sedikit.

Hasil analisis hubungan asupan natrium dengan tekanan darah sistolik pada penelitian ini menunjukkan bahwa tidak terdapat hubungan antara asupan natrium dengan tekanan darah sistolik $(\mathrm{p}=0,310)(\mathrm{p}>0,05)$ dan hasil analisis hubungan asupan natrium dengan tekanan darah diastolik menunjukkan tidak terdapat hubungan $(\mathrm{p}=0,817)(\mathrm{p}>0,05)$. Hal ini sejalan dengan penelitian yang dilakukan oleh Rista Emiria (2012) dimana tidak terdapat hubungan antara asupan natrium dengan tekanan darah sistolik $(\mathrm{p}=0,378)$ maupun diastolik $(\mathrm{p}=0,207) .{ }^{15}$ Begitupun dengan penelitian yang dilakukan oleh Fatimah Kautsar (2014) dimana tidak terdapat hubungan antara asupan natrium dengan tekanan darah $(\mathrm{p}=0,009)$ dimana hal ini dikarenakan subjek penelitian yang diteliti memiliki Indeks Massa Tubuh Overweight dan 
obesitas dimana orang yang overweight dan obesitas memiliki sensitifitas garam yang berpengaruh besar terhadap tekanan darah. ${ }^{16}$

Adapun hubungan asupan kalium dengan tekanan darah sistolik dan diastolik tidak dianalisis karena tidak memenuhi syarat uji yaitu tabel berbentuk 1 x 3 . Dimana asupan kalium responden sebanyak 76 responden dari 76 responden (100\%) memiliki asupan kalium kurang. Asupan kalium kurang ini dikarenakan asupan serat dari responden kurang dimana sumber serat seperti sayur dan buah-buahan juga menjadi sumber kalium.

Hasil analisis yang dilakukan mengenai hubungan kualitas tidur dengan tekanan darah sistolik didapatkan tidak terdapat hubungan antara kualitas tidur dan tekanan darah sistolik $(\mathrm{p}=0,753) \quad(\mathrm{p}>0,05)$ dimana hasil penelitian menunjukkan sebagian besar responden yang diteliti mayoritas memiliki kualitas tidur buruk dengan tekanan darah sistolik normal sebanyak 38 orang $(62,3 \%)$ Begitupun dengan tekanan darah diastolik tidak terdapat hubungan antara kualitas tidur dengan tekanan darah diastolik $(\mathrm{p}=0,861)(\mathrm{p}>0,05)$. Hal ini sejalan dengan penelitian yang dilakukan oleh Nurilmi (2016) dimana tidak terdapat hubungan dengan kualitas tidur dengan tekanan darah $(\mathrm{p}=0,257)$ dan dalam penelitian ini mayoritas responden memiliki kualitas buruk dengan tekanan darah normal. ${ }^{17}$ Hal ini sejalan juga dengan penelitian yang dilakukan oleh Ummul Yaqin (2016) yang menyatakan bahwa tidak terdapat hubungan antara kualitas tidur dengan tekanan darah sistolik $(\mathrm{p}=0,083)$ dan tekanan darah diastolik $(\mathrm{p}=0,292)$. Dimana dalam penelitian ini usia responden yang masih tergolong usia produktif dan jenis kelamin perempuan yang belum memasuki masa menopause cenderung memiliki tekanan darah normal. Hal ini sama dengan penelitian yang dilakukan dimana responden yang diteliti lebih banyak memiliki tekanan darah sistolik normal sebanyak 40 orang $(52,5 \%)$ dan tekanan darah diastolik normal sebanyak 32 orang $(42,1 \%){ }^{18}$

\section{KESIMPULAN}

Kesimpulan dari penelitian ini adalah tidak ada hubungan antara asupan makan (asupan lemak, serat, natrium dan kalium) dengan tekanan darah. Kemudian juga tidak terdapat hubungan antara kualitas tidur dengan tekanan darah. Untuk penelitian selanjutnya diharapkan melakukan penelitian pada mahasiswa yang berbeda disiplin ilmu dari penelitian ini.

\section{DAFTAR PUSTAKA}

1. Padmawinata, K (Penyadur). Pengendalian Hipertensi Laporan Komisi Pakar WHO. Bandung: Penerbit ITB; 2001.

2. WHO. Hypertension. [Internet]. Avalaible from: https://www.who.int/news-room/factsheets/detail/hypertension; 2019.

3. Kementerian Kesehatan RI. Laporan Nasional Hasil Riskesdas 2007. Jakarta: Badan Penelitian dan Pengembangan Kesehatan Republik Indonesia; 2007.

4. Kementerian Kesehatan RI. Laporan Nasional Hasil Riskesdas 2013. Jakarta: Badan Penelitian dan Pengembangan Kesehatan Republik Indonesia; 2013.

5. Kementerian Kesehatan RI. Laporan Nasional Hasil Riskesdas 2018. Jakarta: Badan Penelitian dan Pengembangan Kesehatan Republik Indonesia; 2018

6. Kementerian Kesehatan RI. Laporan Hasil Riskesdas Sulawesi Selatan 2007. Jakarta: Badan Penelitian dan Pengembangan Kesehatan Republik Indonesia; 2007.

7. Kementerian Kesehatan RI. Laporan Hasil Riskesdas Sulawesi Selatan 2013. Jakarta: 
Badan Penelitian dan Pengembangan Kesehatan Republik Indonesia; 2013.

8. Andamsari, M. N. Hubungan Pola Makan dengan Tekanan Darah Pada Orang Dewasa di Sumatera Barat, Jurnal MKA. 2015;38(1).

9. Saharuddin dkk. Hubungan Pola Konsumsi Natrium dan Kalium dengan Kejadian Hipertensi di Puskesmas Paccerakkang Makassar, Berita Kedokteran Masyarakat. 2018;34(5).

10. Widyaningrum, A. T. Hubungan Asupan Natrium, Kalium Magnesium dan Status Gizi dengan Tekanan Darah Pada Lansia di Kelurahan Makamhaji Kecamatan Kartasura [Skripsi sarjana]. Universitas Muhammadiyah Surakarta; 2014.

11. Putri, M. A. Hubungan Asupan Serat, Asupan Natrium dan Aktivitas Fisik dengan Tekanan Darah di Unit Rawat Jalan UPTD Puskesmas Pajang Surakarta [Skripsi sarjana]. Universitas Muhammadiyah Surakarta; 2016.

12. Fitri, A. A. Hubungan Kualitas Tidur Terhadap Kejadian Hipertensi [Skripsi sarjana]. UIN Syarif Hidayatullah Jakarta; 2013.

13. Menad, A. Hubungan Asupan Protein, Lemak, Kalium dan Magnesium Terhadap Tekanan Darah Lansia [Skripsi sarjana]. Universitas Diponegoro; 2016.

14. Rahma, A. Pengukuran Indeks Massa Tubuh, Asupan Lemak dan Asupan Natrium Kaitannya dengan Kejadian Hipertensi Pada Kelompok Dewasa di Kabupaten Jombang, Ghidza Media Journal. 2019;1(1), p. 53-62.

15. Emiria, R. Asupan Protein, Lemak Jenuh, Natrium, Serat dan IMT Terkait dengan Tekanan Darah Pasien Hipertensi di RSUD Tugurejo Semarang, Journal of Nutrition College. 2012;1(1), p. 21-29.

16. Kautsar, F. Hubungan Obesitas, Asupan Natrium dan Kalium dengan Tekanan Darah Pada Mahasiswa Universitas Hasanuddin Angkatan 2013, Media Kesehatan Masyarakat Indonesia. 2014;10(4), p. 187-192.

17. Nurilmi. Hubungan Kualitas Tidur dengan Tekanan Darah Pada Mahasiswa Keperawatan UIN Alauddin Makassar [Skripsi sarjana]. UIN Alauddin Makassar; 2016.

18. Yaqin, U. Hubungan Kualitas Tidur dengan Tekanan Darah Pada Mahasiswa Progran Studi Ilmu Keperawatan Universitas Jember [Skripsi sarjana]. Universitas Jember, 2016. 